\title{
REFLEXÕES ACERCA DA CRIMINALIZAÇÃO DE CONDUTAS IMORAIS: Análise a Partir da Filosofia de Ronald Dworkin
}

\section{Nigel Stewart Neves Patriota Malta}

Doutorando em Educação e mestre em Direito pela Universidade Federal de Alagoas - Ufal. Graduado em Direito e pós-graduado em Formação para a Docência do Ensino Superior pelo Centro Universitário Cesmac. Servidor público no Tribunal de Justiça do Estado de Alagoas - TJAL. Maceió, AL - Brasil. Lattes: <http:// lattes.cnpq.br/3983490925456375>. Orcid: <http://orcid. org/0000-0002-0181-4474>. nigelsnpmalta@gmail.com

\section{Adrualdo de Lima Catão}

Doutor e mestre em Direito pela Universidade Federal de Pernambuco - UFPE. Professor da Faculdade de Direito da Universidade Federal de Alagoas - FDA/Ufal (Graduação e Mestrado), do Centro Universitário Cesmac e do Centro Universitário Tiradentes - Unit. Lattes: <http://lattes.cnpq. br/8192319753819460>. adrualdocatao@gmail.com

\section{Resumo:}

0 presente trabalho objetiva promover uma análise de cunho jurídico-filosófico acerca da criminalização de condutas consideradas contrárias à moral. Ao longo dos últimos anos as discussões sobre a criminalização de algumas condutas consideradas imorais, tais como a pornografia, o aborto e a eutanásia, têm dividido a opinião de diversos estudiosos e setores da sociedade civil. Partindo das posições favoráveis e contrárias à ingerência do Direito no campo da moral, buscar-se-á refletir sobre a temática com base nos estudos de Ronald Dworkin. 0 presente estudo se desenvolveu por meio de revisão bibliográfica, com a pesquisa sendo efetivada, quanto à abordagem, de forma qualitativa.

\section{Palavras-chave:}

Criminalização. Moral. Direito. Liberalismo. Ronald Dworkin. 


\section{REFLECTIONS ON THE CRIMINALIZATION OF IMMORAL CONDUCT: ANALYSIS FROM THE PHILOSOPHY OF RONALD DWORKIN}

\section{Abstract}

The present work aims to promote a legal-philosophical analysis about the criminalization of conduct considered to be contrary to morality. Over the last few years, discussions about the criminalization of some conduct considered immoral, such as pornography, abortion and euthanasia, have divided the opinion of many scholars and sectors of civil society. Starting from the favorable positions and contrary to the interference of the law in the field of the moral, will be looked for to reflect on the thematic one based on the studies of Ronald Dworkin. The present study was developed through a bibliographic review, and the research was carried out qualitatively in terms of the approach.

\section{Keywords:}

Criminalization. Moral. Law. Liberalism. Ronald Dworkin.

Recebido em: 12/11/2017

Aceito em: 13/1/2018

\section{Sumário:}

1 Introdução. 2 A Relação Entre Moral, Direito e Liberdade. 3 A Criminalização de Condutas Imorais: Pornografia, Aborto e Eutanásia. 4 Reflexões a Partir da Filosofia de Ronald Dworkin. 4.1 A Questão da Pornografia. 4.2 A Questão do Aborto. 4.3 A Questão da Eutanásia. 5 Considerações Finais. 6 Referências. 


\section{INTRODUÇÃO}

As condutas praticadas pelo ser humano e a moralidade delas constituem temas que suscitam debates intensos e infindáveis. É o caso, por exemplo, de condutas como a pornografia, o aborto e a eutanásia, consideradas por uma boa parte da sociedade como contrárias à moral.

Tal discussão tem ultrapassado o campo da moral, considerando que diversas condutas de aspecto estritamente moral passaram a ter a ingerência do Direito. Nesse aspecto, é sabido que a moral tem sua importância perante o Direito, exercendo significativa influência na escolha dos bens jurídicos que deverão ser tutelados. Não obstante, nem tudo que faz parte do âmbito moral deve integrar o Direito, até porque existem normas jurídicas puramente morais, mas também normas imorais (contrárias à moral) ou amorais (indiferentes à moral).

Isso posto, nem sempre uma conduta considerada ilícito moral deve também ser classificada como ilegal ou tratada pelo Direito como crime. Sob esse prisma, importante ressaltar que o Estado não deve impor legalmente aos cidadãos as convicçôes morais da maioria, sob pena de infringir a liberdade individual do ser humano.

Nesse contexto, o objetivo geral do presente estudo é discutir a criminalização de condutas contrárias à moral a partir da filosofia de Ronald Dworkin. Visando à abordagem de todo o conteúdo de forma harmônica e dinâmica, pretende-se, quanto aos objetivos específicos, abordar a relação entre a moral, o direito e a liberdade e a ingerência do Direito Penal na tipificação de condutas consideradas imorais. A partir disso, buscar-se-á promover estudo sobre a criminalização da pornografia, do aborto e da eutanásia, à luz dos escritos do referenciado filósofo.

\section{A RELAÇÃO ENTRE MORAL, DIREITO E LIBERDADE}

A relação entre moral, direito e liberdade apresenta imbricaçôes de larga extensão, de modo que o presente item não tem a pretensão de esgotar o assunto, mas somente identificar como esses fenômenos interagem entre si. O estudo sobre 
a relação entre moral, direito e liberdade requer a exposição dos seus conceitos. A partir da compreensão acerca da moral, do direito e da liberdade, constata-se a interação existente entre eles.

A palavra moral é derivada do vocábulo em latim morus, que significa conjunto de usos, costumes, práticas e padróes de conduta em um determinado segmento da sociedade (VENOSA, 2009). Para Reale (2002, p. 37), moral é a "parte da Filosofia que trata dos costumes e dos deveres que os homens têm em relação aos seus semelhantes e à sua consciência. Aquilo que é honesto e apropriado com os bons costumes". Por sua vez, Villey (2008) expóe que a moral, na análise aristotélica, é a arte que se interessa pela virtude subjetiva do indivíduo, preceituando condutas, sobretudo as justas, ou as do homem justo.

Em outras palavras, a moral refere-se aos valores, costumes e normas de conduta típicos de uma cultura ou sociedade. É o complexo de valores que conjugam as açóes do ser humano (VELOSO, 2005).

No que se relaciona ao Direito, palavra plurívoca, há diversos significados, todos entrelaçados. $\mathrm{O}$ termo Direito, originário do brocardo romano tradicional ius, traduz a ideia da arte do bom e do equitativo (ars boni et aequi). Assim, em primeiro plano, o Direito é visto como arte e como ciência, apesar de ter conquistado outros sentidos (VENOSA, 2009).

Etimologicamente, a palavra direito é derivada do latim directum, do verbo dirigere (dirigir, ordenar, endireitar). $\mathrm{O}$ vocábulo significa aquilo que é reto, que não se desvia, que segue uma só direção. Assim, por direito entende-se tudo aquilo que é de acordo com a justiça, a razão e a equidade (SILVA, 1999).

O sentido a ser empregado neste estudo diz respeito ao Direito como ciência, ou seja, quando sua análise visa à elaboração de "normas de conduta a serem respeitadas por cada indivíduo e voltadas para o interesse e bem-estar da coletividade" (SECCO, 2001, p. 5). Esse sentido enfeixa o estudo e a compreensão das normas postas pelo Estado ou pela natureza do homem. Nesse caso, a cientificidade náo apenas se limita a apresentar e classificar regras, mas também tem como finalidade analisar e estabelecer princípios para os fenômenos sociais, por exemplo: a obrigação; os negócios jurídicos; a filiação; o casamento; o poder familiar; a propriedade, etc. (VENOSA, 2009). 
Quanto à liberdade, é possível concebê-la como a propriedade da vontade se determinar por sua própria energia, sem existência de força ou coação. Em outras palavras, diz respeito à açáo livre e por vontade espontânea (BITTAR, 2005). O significado de liberdade está relacionado à premissa de que o homem é um ser livre e que, por esse motivo, tem o poder de acordar o seu arbítrio com o dos demais, conforme uma lei geral de liberdade (REALE, 1999).

A liberdade, contextualizada historicamente, conquistou um espaço importante a partir do episódio conhecido como queda ou Tomada da Bastilha, ${ }^{1}$ marco histórico da Revolução Francesa - embasada nos ideais de liberdade, igualdade e fraternidade - manifestando-se em duas perspectivas distintas, mas que se complementam: $i$ ) limitação da soberania e da açáo do Estado e ii) garantia da autonomia da vontade do cidadão (BITTAR, 2005). Conforme a ideia ou o sentido atribuído por Reale (1999, p. 657), "liberdade implica a convicção de que existe uma esfera peculiar e própria de ação reservada aos indivíduos, insuscetível de interferência ou de contrasteação por parte do Estado".

Hayek, ao conceituar liberdade, notadamente aquela relacionada à esfera individual - subjetiva - expóe que ela se refere "à possibilidade de uma pessoa pautar-se em suas açóes por sua própria vontade e consciência, por sua razão ou firme convicção e não por circunstâncias ou impulsos momentâneos" (1983, p. 9).

Com esse breve introito já é possível abstrair a intrínseca relação havida entre a moral, o direito e a liberdade. Observa-se que, apesar de resguardarem significados diversos, cada qual com suas características peculiares, é impossível separá-los. É o caso, por exemplo, da moral e do Direito, que são instrumentos de controle social distintos, mas que não se excluem. Aliás, a moral e o Direito complementam-se e reciprocamente se influenciam.

${ }^{1}$ A Tomada da Bastilha (La prise de la Bastille) aconteceu no ano de 1789. A Bastilha inicialmente foi construída como uma fortaleza pelo rei da França Carlos V, em 1370, tendo, a partir do século 17 , sido destinada ao aprisionamento de pessoas contrárias à política dominante. Era considerada o "símbolo espectral do absolutismo e do feudalismo. Para os iluministas, a Bastilha era, desde 1750, um símbolo de um regime em falência” (MENEZES, 1989, p. 77). 
Uma das principais teorias que analisam a relação entre a moral e o Direito é a chamada teoria do mínimo ético, ${ }^{2}$ desenvolvida pelo filósofo inglês Jeremy Bentham e posteriormente aperfeiçoada pelo jurista alemão Georg Jellinek, no fim do século 19. Na teoria do mínimo ético, o Direito e a moral são ilustrados como dois círculos concêntricos, de modo que o círculo que representa o Direito é o menor. Essa teoria, entretanto, não condiz com a realidade. De fato, muitas normas jurídicas são também normas morais, mas há também normas jurídicas que estão aquém dos princípios morais ou se posicionando além destes. É o que assevera o tradicional brocardo "nem tudo que é justo é honesto" (VENOSA, 2009).

Nessa esteira, existe aquilo que é imoral (contrário à moral), assim como existe aquilo que é apenas amoral (indiferente à moral), de modo que é necessário distinguir um campo do Direito no qual existem normas jurídicas que, se não são imorais, são, no mínimo, amorais, razão pela qual o Direito e a moral podem ser representados por dois círculos secantes. Na relaçáo entre o Direito e a moral, a representação de dois círculos concêntricos corresponde à concepção ideal, enquanto a representação de dois círculos secantes corresponde à concepção real ou pragmática (REALE, 2002).

Assim, depreende-se que, apesar de Direito e moral serem fenômenos distintos, cada um com suas especificidades e objetivos, acham-se interligados entre si $^{3}$ (NADER, 2014). Cabe registrar que há uma diferença sensível entre a moral,

${ }^{2}$ A respeito dessa teoria, Reale (2002, p. 42) preleciona que: “A teoria do 'mínimo ético' consiste em dizer que o Direito representa apenas o mínimo de Moral declarado obrigatório para que a sociedade possa sobreviver. Como nem todos podem ou querem realizar de maneira espontânea as obrigaçóes morais, é indispensável armar de força certos preceitos éticos, para que a sociedade não soçobre. A Moral, em regra, dizem os adeptos dessa doutrina, é cumprida de maneira espontânea, mas como as violaçóes são inevitáveis, é indispensável que se impeça, com mais vigor e rigor, a transgressão dos dispositivos que a comunidade considerar indispensáveis à paz social. Assim sendo, o Direito não é algo diverso da Moral, mas é uma parte desta, armada de garantias específicas."

3 A esse respeito, Nader (2014, p. 63) expóe que "Direito e Moral são instrumentos de controle social que não se excluem, antes, se completam e mutuamente se influenciam. Embora cada qual tenha seu objetivo próprio, é indispensável que a análise cuidadosa do assunto mostre a ação conjunta desses processos, evitando-se colocar um abismo entre o Direito e a Moral. Seria um grave erro, portanto, pretender-se a separaçáo ou o isolamento de ambos, como se fossem sistemas absolutamente autônomos, sem qualquer comunicação, estranhos entre si. O Direito, malgrado distinguir-se cientificamente da Moral, é grandemente influenciado por esta, de quem recebe valiosa substância". 
que tem caráter espontâneo, e o Direito, que possui a natureza obrigatória. $\mathrm{O}$ que distingue a moral do Direito, portanto, é a coercibilidade, pois a moral é incoercível e o Direito é coercível (REALE, 2002).

Com efeito, pode-se afirmar que o Direito é heterônomo, tendo em vista que o cidadáo é compelido a cumprir a norma jurídica. É o caso do pagamento de impostos, que gera para o cidadão uma obrigaçáo decorrente de lei. Em contrapartida, a moral é autônoma, uma vez que ninguém é obrigado a cumprir a norma moral. O cidadão só oferece esmola, como exemplo, por força de sua consciência (SIQUEIRA JR., 2002).

O caráter espontâneo da moral está relacionado ao mundo do comportamento que encontra em si próprio a razão de existir. É o mundo da conduta espontânea, pois o ato moral provoca a adoção do espírito ao conteúdo da regra. Isto é, não existe ato moral quando é praticado de modo forçado ou coagido (REALE, 2002).

Nesse aspecto, a liberdade conecta-se à moral, pois o ser humano tem a capacidade de escolher, de acordo com a sua consciência, se cumpre ou não uma norma moral. Sem a liberdade é impossível ao homem desenvolver uma consciência moral e praticar uma conduta assim considerada. O homem é um ser livre por natureza, de modo que a escolha pelo cumprimento ou não de uma norma moral perpassa diretamente pelo julgamento de consciência (liberdade) do próprio indivíduo.

De acordo com Bittar (2005), encontra-se, a moral, centralizada na liberdade, pois é por meio desta que o homem se torna independente e decide pela prática de determinados comportamentos. A liberdade, na condição de escolha de valores morais, é o que concede especificidade ao ser humano, assim como é por meio dela que o homem se torna capaz de criar um mundo contraposto ao da natureza, o mundo ético.

Insta salientar que, de acordo com a moral kantiana, o "homem não deve agir desta ou daquela maneira, por ser livre, mas é livre porque deve fazer algo que lhe dita a consciência de modo irrefragável” (REALE, 1999, p. 690). Sob essa perspectiva verifica-se que a liberdade encontra o seu ápice quando se relaciona com a moral. Isso porque, por ser livre, o ser humano pode cumprir ou não as normas morais. Nesse caso, a liberdade é exercida de forma plena e sem restriçóes, razão 
pela qual, por livre e espontânea vontade, o indivíduo pode agir de forma moral, amoral ou imoral, náo sofrendo quaisquer sançóes legais, exceto se a conduta for abarcada pelo Direito.

Quando se relaciona com o Direito, contudo, a liberdade náo alcança o seu ponto máximo. Em que pese ser livre, o cidadão é obrigado a cumprir a lei, sob pena de sofrer as sanções por ela impostas. Nessa situação, a liberdade não é plenamente exercida, uma vez que o cidadão fica condicionado às restriçóes estabelecidas pela norma jurídica, em consequência da cessão implícita de parcela da autonomia individual em prol da sociabilidade.

À luz do Estado de Direito, nada pode ser arbitrário. A lei serve de parâmetro para o comportamento do ser humano, de modo que a limitação de sua liberdade somente pode ser condicionada pela norma jurídica, ou seja, apenas a lei tem o condão de compelir a execução de um dever, ou impedir a execução de determinado ato (BITTAR, 2005).

A liberdade é um direito fundamental do ser humano, com amparo nos principais diplomas jurídicos internacionais e também na Constituição Federal (CF) brasileira de 1988. Ressalta-se que a própria CF assegura o direito à liberdade, ${ }^{4}$ podendo ser limitada apenas por preceito de lei. Nessa linha, a imposição de limites à liberdade do cidadão é necessária. O homem é capaz de tudo, quer seja de praticar a melhor das açóes, quer seja de agir de forma bestial. Nesse sentido, uma importante contribuição proporcionada pela instituição do Estado de Direito é no sentido de que a limitação da liberdade do ser humano somente pode ser realizada pela norma jurídica (BITTAR, 2005).

Percebe-se, então, que o ser humano não pode exercer sua liberdade de modo excessivo, caso contrário poderia violar a liberdade ou qualquer outro direito de seu semelhante. Logo, a liberdade do homem sujeita-se, pelo menos, ao justo e adequado comando da lei.

\footnotetext{
${ }^{4}$ Art. $5^{\circ}$ - Todos são iguais perante a lei, sem distinção de qualquer natureza, garantindo-se aos brasileiros e aos estrangeiros residentes no país a inviolabilidade do direito à vida, à liberdade, à igualdade, à segurança e à propriedade, nos termos seguintes: [...] II - ninguém será obrigado a fazer ou deixar de fazer alguma coisa senão em virtude de lei (BRASIL, 1988, grifos nossos).
} 
Isso não significa que direito e liberdade se contrapóem, porquanto somente é possível falar de preceito normativo e de sua vigência, admitindo-se que o ser humano possui um poder capaz de superar naturalmente as funçôes necessárias da vida psíquica, possibilitando o cumprimento da prescrição normativa. Esse poder é a liberdade, compreendida como o domínio do homem sobre sua consciência. $\mathrm{Na}$ relação com o Direito, a liberdade é a determinação da consciência empírica pela consciência normativa (REALE, 1999).

Assim, nota-se a existência de uma relação intrínseca entre moral, direito e liberdade, sobre a qual se faz necessária a reflexão, sobretudo quando se discute a criminalização de condutas imorais.

\section{A CRIMINALIZAÇÃO DE CONDUTAS IMORAIS: Pornografia, Aborto e Eutanásia}

Como já introduzido neste estudo, moral e Direito são instrumentos de controle social que se complementam e reciprocamente se influenciam. A moral, tida como um conjunto de valores, usos, costumes, práticas e padróes de conduta de um determinado segmento social que influencia diretamente na construção do ordenamento jurídico, ${ }^{5}$ representa parcela do Direito.

Em diversas situaçôes é possível constatar a importância da moral para o Direito. A própria obediência dos cidadãos às normas jurídicas está relacionada à moral. Segundo Catão (2014, p. 86), "também não se pode negar a relação entre o conteúdo moral e o direito, quando as normas jurídicas refletem valores morais". Aliás, a moral também tem grande valia nas decisões proferidas pelos órgãos jurisdicionais (CATÃO, 2014).

5 De acordo com as liçôes de Ferraz Júnior (2015, p. 321), “[...] é preciso reconhecer certa similaridade entre normas jurídicas e preceitos morais. Ambos têm caráter prescritivo, vinculam e estabelecem obrigaçóes numa forma objetiva, isto é, independentemente do consentimento subjetivo individual. Ambos são elementos inextirpáveis da convivência, pois, se não há sociedade sem direito, também não há sociedade sem moral". 
As normas jurídicas são consideravelmente distintas das outras modalidades de normas, sobretudo em razáo de suas características peculiares. As normas morais, contudo, ostentam, sem dúvida, parentesco muito próximo com as normas jurídicas, ${ }^{6}$ sendo as que mais se conciliam e se relacionam com o Direito (VENOSA, 2009).

Nesse contexto, emerge a discussão sobre o Direito Penal regular aquilo que é definido como ilícito moral. É o caso da criminalização de condutas imorais, tais como a pornografia, o aborto e a eutanásia.

O raciocínio é o de que, se as normas jurídicas consideram lícitos os usos, costumes e valores que sáo classificados pela sociedade como normas morais, consequentemente devem considerar ilícitas as condutas tachadas como imorais.

Náo obstante, apesar da relação entre as normas jurídicas e as normas morais, é importante ressaltar que o Direito e a moral são campos distintos. Nem tudo que integra o campo moral deve igualmente integrar o campo do Direito. $\mathrm{O}$ fato é que existem condutas imorais que à luz do Direito são consideradas lícitas. ${ }^{7}$

Observa-se, pois, que a função do Direito não é vigiar a virtude do cidadão, tampouco regular a sua conduta. No Direito, não importa que subjetivamente o ser humano seja honesto e cheio de boas intençóes. ${ }^{8}$ Existe, todavia, um clamor

${ }^{6}$ Convergindo com esse entendimento, Veloso (2005, p. 84) expóe que: "Embora pertencentes a sistemas de normas distintas, as obrigaçôes advindas do Direito e da Moral são parceiras e irmãs. Diferentes, distintas, mas parceiras e irmâs. Normalmente, o que se observa é que as prescriçôes do Direito são, também, de ordem moral. As poucas normas do Direito que não são também e cumulativamente morais são as do mundo não integrante do 'estado de direito', ou seja, as regras que foram feitas com vistas apenas a interesses individuais de manutenção e desvio do poder".

7 Exemplificando, Reale (1999, p. 43) afirma: "Lembre-se o exemplo de uma sociedade comercial de dois sócios, na qual um deles se dedica, de corpo e alma, aos objetivos da empresa, enquanto o outro repousa no trabalho alheio, prestando, de longe em longe, uma rala colaboração para fazer jus aos lucros sociais. Se o contrato social estabelecer para cada sócio uma compensação igual, ambos receberão o mesmo quinhão. E eu pergunto: é moral? Há, portanto, um campo da Moral que não se confunde com o campo jurídico".

8 Quanto à tutela de condutas imorais pelo Direito, Reale (1999, p. 43) posiciona-se da seguinte forma: "O Direito, infelizmente, tutela muita coisa que não é moral. Embora possa provocar nossa revolta, tal fato não pode ficar no esquecimento. Muitas relaçóes amorais ou imorais realizam-se à sombra da lei, crescendo e se desenvolvendo sem meios de obstá-las. Existe, porém, o desejo incoercível de que o Direito tutele só o 'lícito moral', mas, por mais que os homens se esforcem nesse sentido, apesar de todas as providências cabíveis, sempre permanece um resíduo de imoral tutelado pelo Direito". 
por uma atuação mais ampla do Direito, sobretudo do seu âmbito penal, muito por conta da aparente incapacidade de atuação de outros mecanismos de controle social à contenção de riscos, embora tal clamor também se deva ao fato de um maior desprestígio das normas morais (ROMA, 2017).

Insta salientar que o Direito Penal é orientado pelo princípio da subsidiariedade, o qual somente autoriza a sua atuação quando os outros ramos do Direito se mostrarem falhos ou insuficientes (ANDREUCCI, 2014). À luz do Direito Penal moderno, fundamentado na noção de Constituição, sobretudo na ideia de Estado Democrático de Direito, a proteção de bens jurídicos é um dos elementos que devem guiar a intervenção penal, em conformidade com a finalidade de proteção subsidiária dos bens jurídicos. Diante disto, exclui-se a tutela penal de condutas imorais ou contravenções, sendo vedada a sua criminalização (ROMA, 2017).

O Direito Penal deve ser visto como um ramo subsidiário em relação aos demais ramos do Direito. Isto significa que, quando os outros mecanismos de composição de conflitos e formas de punição não surtem o objetivo esperado, emerge a necessidade da tutela penal para coibir condutas desregradas e que possam lesionar bens jurídicos relevantes (NUCCI, 2014).

A subsidiariedade do Direito Penal apresenta-se como substrato do princípio da intervenção mínima, ${ }^{9}$ que também é conhecido como ultima ratio, nascido com vinculação ao pensamento iluminista e com a pretensão de redução, em linhas gerais, da legislação e, especialmente, das leis penais ${ }^{10}$ (BARROS LIMA, 2012, p. 69). Sob esse viés, a intervenção mínima tem como escopo a orientação e a limitação do

9 Quanto ao princípio da intervenção mínima, Mirabete (2006, p. 108) aduz que "O ordenamento positivo, pois, deve ter como excepcional a previsão de sançóes penais e não se apresentar como um instrumento de satisfação de situaçôes contingentes e particulares, muitas vezes servindo apenas a interesses políticos do momento para aplacar o clamor público exacerbado pela propaganda. [...] Essas idéias, consubstanciadas no chamado princípio da intervenção mínima, servem para inspirar o legislador, que deve buscar na realidade fática o substancial deve-ser para tornar efetiva a tutela dos bens e interesses considerados relevantes quando dos movimentos de criminalização, neocriminalização, descriminalização e despenalizaçáo".

${ }^{10}$ Nesse contexto, o citado autor expóe como principal motivo originador do referenciado princípio "a preocupação com o excessivo número de leis e os tentáculos do absolutismo despótico, que pairavam, ameaçadoramente, contra a já hegemônica burguesia" como o "pano de fundo para o repúdio às normas que ainda eram editadas pela nova classe que ascendia ao poder" (BARROS LIMA, 2012, p. 69). 
poder incriminador do Estado; a criminalização de um comportamento somente é considerada legítima caso se constate ser o meio necessário para prevenir a lesão contra bens jurídicos importantes (BITENCOURT, 2012).

A ideia do ius puniendi estatal por meio da proteção subsidiária do bem jurídico, apresenta-se como uma solução racional. O legislador penal que acolher essa concepção, consequentemente, proibirá incriminaçóes arbitrárias que não tutelam bens jurídicos, assim como tipificaçôes puramente ideológicas e meramente imorais. Ademais, os próprios princípios constitucionais que limitam a atuação do legislador proíbem que o Direito Penal sirva de proteção a bens jurídicos desprovidos de importância (ROMA, 2017).

Com efeito, o Direito Penal dedica-se a tutelar somente os bens jurídicos mais importantes e as condutas mais graves. É o que a doutrina denomina de princípio da fragmentariedade ${ }^{11}$ no Direito Penal, que é um desdobramento do princípio da intervenção mínima.

Logo, se nem todas as condutas que ocasionam lesão a bens jurídicos são alvo de proibição pelo Direito Penal, menos ainda aquelas açóes que se restringem exclusivamente ao campo moral. O caráter fragmentário do Direito Penal impóe que o legislador opte pela proteção de bens jurídicos essenciais nos casos em que a lesão for de maior intensidade.

Importa-nos discutir sobre a criminalização de condutas imorais, tais como a pornografia, o aborto e a eutanásia, com base nas reflexóes advindas dos estudos de Ronald Dworkin.

\section{REFLEXÕES A PARTIR DA FILOSOFIA DE RONALD DWORKIN}

No presente ensaio alocou-se como cerne do estudo proposto a reflexão sobre a criminalização de condutas imorais a partir da filosofia de Ronald Dworkin. Desse modo, pretende-se analisar a pornografia, o aborto e a eutanásia como condutas imorais e sujeitas à criminalização, a partir da posição do mencionado filósofo.

${ }^{11}$ De acordo com o entendimento de Bitencourt (2012, p. 530): "Nem todas as ações que lesionam bens jurídicos sáo proibidas pelo Direito Penal, como nem todos os bens jurídicos são por ele protegidos. O Direito Penal limita-se a castigar as açóes mais graves praticadas contra os bens jurídicos mais importantes, decorrendo daí o seu caráter fragmentário, uma vez se ocupa somente de uma parte dos bens jurídicos protegidos pela ordem jurídica”. 


\subsection{A questão da pornografia}

A pornografia pode ser conceituada como todo experimento do ser humano, e o produto ou objeto desse experimento, que tem como objetivo excitar a libido de um público passivo, atraindo-lhe a atenção e estimulando o consumo (LOPES, 2016). No que se refere a sua criminalização, cabe registrar que existem diversas formas de pornografias; algumas delas, segundo Dworkin (2001), devem ser proibidas ou restringidas:

Certas formas de pornografia devem ser inteiramente proibidas. Estas incluem espetáculos de sexo ao vivo (cópula, sexo oral e similares efetivos, não simulados, executados ao vivo diante de um público) e filmes e fotografias produzidos por meio da exploraçáo de crianças. Outras formas de pornografia não devem ser proibidas, mas restringidas de várias maneiras. As restrições incluem normas sobre exibição ou propaganda ofensivas em locais públicos, limitação da venda de pornografia em lojas especializadas e um esquema elaborado de exame prévio e autorização de filmes ( p. 499).

Não obstante, em algumas sociedades há um clamor público pela criminalização da pornografia em todas as suas formas. É o que ocorre, por exemplo, nos Estados Unidos e no Reino Unido. Nesses países, a maioria das pessoas prefere a censura substancial, quando não a total proibição de filmes, fotografias, livros e revistas de conteúdo sexual explícito. Ocorre que, de acordo com Dworkin, são essas pessoas que fazem consumo da pornografia, aliás, isso faz parte da psicologia do sexo, de modo que muitos nutrem um gosto fixo pelo sexo, porém preferem resistentemente que os seus filhos náo os acompanhem nesse gosto, e por isso desejam a criminalização (DWORKIN, 2001). De mais a mais, para o referenciado autor, os motivos utilizados pelos defensores da criminalização da pornografia podem ser diversos:

Pode julgar ou acreditar, por exemplo, que seu prazer pelos corpos de outras pessoas é diminuído ou fica menos intenso e especial quando a nudez se torna excessivamente familiar para ele ou menos peculiar às ocasiōes em que lhe oferece prazer especial, que podem ser no museu, no seu quarto, ou em ambos. Ou que o sexo passará a ser diferente e menos valioso para ele se lhe for lembrado, com muita frequência e vigor, que tem um significado diferente, mais comercial ou 
mais sádico, para outros. Ou que seu objetivo, de que seus filhos desenvolvam gostos e opinióes similares, será frustrado pela exibiçáo ou propaganda a que ele se opóe (p. 529).

Ademais, uma parcela da sociedade entende que as pessoas que publicam e consomem pornografia estão fazendo algo errado ou, no mínimo, estáo a exibir o tipo errado de caráter (DWORKIN, 2001). Nesse sentido, a pornografia é compreendida como um ilícito moral, e pelo fato de revelar uma conduta supostamente errônea ou um desvio de caráter do indivíduo, alguns defendem a sua criminalização.

O que acontece de fato, entretanto, é que boa parte dos indivíduos não gosta de encontrar material que contém sexo explícito ou não se sentem confortáveis de que esse material esteja sendo disponibilizado. Apesar disso, esse gosto não pode necessariamente refletir uma opinião adversa a respeito do caráter das pessoas que não se importam com isso. Por exemplo, as pessoas que esperam que o Estado produza exclusivamente clássicos do teatro não devem pensar que aqueles que preferem o teatro experimental são seres humanos menos dignos (DWORKIN, 2001).

$\mathrm{Na}$ verdade o que motiva algumas pessoas ao sustento da opiniáo pela criminalizaçáo da pornografia são os valores morais incutidos em sua consciência, como bem explica Dworkin (2001, p. 530):

Além disso, mesmo se considerarmos literalmente a descrição dos motivos das pessoas no argumento que expus, somos obrigados a reconhecer a significativa influência das convicçóes morais nesses motivos, pois a idéia que uma pessoa tem acerca daquilo que deseja que sejam suas posturas para com o sexo e, com certeza, sua idéia acerca das posturas que espera encorajar em seus filhos, não apenas são influenciadas, mas constituídas por suas opiniôes morais, no sentido amplo. Encontramos, portanto, nos motivos das pessoas para reprovar a propaganda ou a exibiçáo de pornografia, pelo menos uma mistura e interaçáo de posturas, crenças e gostos que excluem qualquer asserçáo segura de que a regulamentação justificada pelo recurso a esses motivos não violaria o direito à independência moral.

É importante destacar ainda que o cidadão possui o direito à liberdade de escolha, podendo, por exemplo, deliberar sobre a leitura ou não de romances sádicos, ou também de admirar fotografias de conteúdo sexualmente explícito. Essa 
liberdade é uma condição essencial e bastante desejável para a prosperidade do ser humano. Em outras palavras, é uma condição inadequada proibir as pessoas que desejam consumir a pornografia, mas não podem fazê-lo por causa de sua criminalização (DWORKIN, 2001).

\subsection{A questão do aborto}

Quanto à conduta do aborto, tem-se que esta pode ser compreendida como o ato de matar deliberadamente um embriāo humano em formação. Nesse caso, a morte é escolhida antes que a vida se tenha realmente iniciado (DWORKIN, 2003). O aborto é um tema multidisciplinar e, sobretudo, moral. Os conservadores sustentam que o aborto é um ilícito moral; defendem também a sua criminalização. Os liberais, entretanto, entendem que o aborto é uma questão puramente moral, não devendo ser objeto de interferência do Direito Penal.

Nesse contexto, observa-se que a problemática gira em torno de uma questão: Qual o momento em que o embriấo se torna um sujeito com direitos e interesses próprios, incluindo o direito à vida? Na opinião de Dworkin (2003), esse problema é uma questáo moral e metafísica, envolvendo diversas áreas da ciência e do conhecimento humano:

Os que sustentam que a decisão cabe à mulher defendem o aborto com base na afirmação de que o embrião é uma criança tanto quanto uma semente já é uma árvore. Em sua maior parte, as discussões teológicas, morais, filosóficas e, inclusive, sociológicas sobre o aborto pressupóem que as pessoas divergem quanto a se o feto é uma pessoa com direito à vida desde o momento de sua concepção, ou se se torna uma pessoa em algum momento da gravidez, ou se não se tornará uma criança enquanto não nascer. E também divergem quanto a se, admitindo-se que o feto já seja uma pessoa, seu direito à vida deve ou não curvar-se diante de algum direito mais forte da gestante (DWORKIN, 2003, p. 41).

Apesar da divergência entre liberais e conservadores, não apenas a respeito do momento em que o embrião teria direito à vida, mas também referente à criminalizaçáo do aborto, percebe-se um consenso de que o aborto pode ser admitido em algumas situaçôes excepcionais. É o caso, por exemplo, da permissão da prática 
do aborto quando for a medida necessária para salvar a vida da mãe, justificando-se por se tratar de uma questáo de autodefesa. O aborto também é moralmente permissível quando a gravidez é fruto de um estupro ou incesto. A grande maioria dos conservadores admite o aborto em situaçóes excepcionais, e poucos são aqueles que sustentam que essa prática não se justifica mesmo em casos isolados (DWORKIN, 2003). Assim, o pensamento conservador é que o aborto constitui uma conduta que deve ser criminalizada, salvo nos casos anteriormente mencionados, tendo em vista que o feto é um sujeito de direitos, entre os quais se insere o direito à vida.

Em contrapartida, a concepçáo liberal admite o aborto, mas sem negar o fato de que o embrião seja um sujeito de direitos. $\mathrm{Na}$ verdade, pressupóe-se que existem outros valores ainda mais importantes que estão em jogo quando se decide pela interrupção de uma gravidez (DWORKIN, 2003). É o caso, por exemplo, do aborto praticado nos casos em que se diagnosticou uma grave anomalia fetal, de modo que se a gravidez for levada a termo existe a possibilidade de que a criança tenha uma vida sofrida, frustrante e breve. Isto é, na concepção liberal, quando a anomalia é bastante complicada e a vida potencial estiver fadada a uma deformidade cruel e à brevidade, entende-se que o aborto não somente é permitido moralmente, como se apresenta como uma necessidade moral, visto ser um erro trazer ao mundo, de forma consciente, uma criança nessas condições (DWORKIN, 2003).

Além disso, o aborto poderia ser permitido quando a mãe está preocupada com os seus próprios interesses, ou seja, quando as consequências do nascimento forem trágicas para a vida da mulher e de sua família. A depender das circunstâncias, a interrupção da gravidez justifica-se quando a mãe tem de abandonar a escola, abrir mão de sua carreira ou de uma vida independente e satisfatória. De fato, para a maioria das mulheres esses casos são os mais difíceis e podem levar a algum sentimento de arrependimento caso realize o aborto. Ainda assim, no pensamento liberal, a mulher não pode ser considerada egoísta, imoral ou ser condenada por sua decisão (DWORKIN, 2003).

Observa-se, pois, que a concepção liberal não nega que o embrião é detentor do direito à vida, porém quando se discute sobre o aborto não se deve debater a partir dos direitos ou interesses do feto, senão de valores intrínsecos (DWORKIN, 2003). Isso, contudo, não significa que o indivíduo pode responder às grandes questôes morais ou jurídicas apenas com base nos próprios valores morais. Quando 
se trata de questốes como o aborto, a grande maioria das pessoas se deixa levar por seus valores morais, assumindo um compromisso de lealdade em defendê-los. $\mathrm{O}$ indivíduo não busca formar sua opinião como cidadão, mas como religioso, ateu, feminista, crítico social, anarquista ou adepto de alguma outra concepção ortodoxa ou radical sobre a sociedade e a justiça (DWORKIN, 2003).

Aliás, nos diversos casos relatados anteriormente, percebe-se que a suposta imoralidade do aborto pode ser relativizada a depender das circunstâncias da situação e dos próprios valores da pessoa. Por esse motivo, além das questôes afetas à saúde pública, vinculadas à presente discussão, não é prudente a criminalização do aborto, pois o governo náo deve ter o poder de ditar a moral privada de nenhuma pessoa, o que pode implicar ofensa ao direito à liberdade e à privacidade.

Dworkin (2003, p. 46) corrobora esse entendimento:

[...] a opinião de que, ao menos na fase final da gravidez, quando o feto já se desenvolveu o bastante para ter interesses próprios, o Estado não deve intervir nem mesmo para impedir os abortos não permissíveis moralmente, uma vez que, em última instância, a questáo de saber se um aborto se justifica ou não deve ser decidida pela mulher que traz consigo o feto. Outros - o companheiro, a família, os amigos, o público - podem desaprovar, e é possível que moralmente estejam certos em fazê-lo. Em certas circunstâncias, a lei pode obrigá-la a discutir sua decisão com outras pessoas. Ao final, porém, o Estado deve deixar que ela decida por si mesma; não deve impor-lhe as convicções morais de terceiros.

Dessa maneira, ainda que por conta das circunstâncias da situação o aborto não seja moralmente permissível, o Estado não deveria criminalizá-lo, pois a decisão final sobre a interrupção da gravidez, e se esta é uma medida justificável, deve ser dos pais do nascituro.

\subsection{A questão da eutanásia}

Por sua vez, no que se refere à eutanásia, tem-se que esta pode ser compreendida como matar deliberadamente um ser humano por razóes de benevolência. É uma opção pela morte após a vida realmente ter começado (DWORKIN, 2003). Nas últimas décadas o debate sobre a eutanásia conquistou espaço nas primeiras páginas dos jornais. Isso porque os médicos começaram a admitir claramente uma 
conduta profissional que costumeiramente era mantida em segredo: a interrupção da existência dos pacientes que pedem para morrer, ou, pelo menos, o auxílio para findar sua vida (DWORKIN, 2003).

Tal problemática diz respeito aos familiares e/ou aos profissionais da saúde que detêm o controle de aparatos tecnológicos com capacidade de manter vivos, seja por semanas ou até mesmo por anos, pessoas que se encontram à beira da morte ou incapacitadas, com dores ou no limiar da inconsciência, devido aos efeitos sedativos. Nesse caso, o indivíduo fica ligado a diversos aparelhos sem os quais perderia a maioria de suas funçóes vitais. Isso evidencia como a situação é aterrorizante para qualquer ser humano, uma vez que a maior parte das pessoas (ou todas as pessoas) carrega consigo o medo de viver inconsciente, ainda que esteja sob cuidados (DWORKIN, 2003).

$\mathrm{Na}$ concepção conservadora, a eutanásia é compreendida como um ilícito moral, de modo que deve também ser regulada pelo Direito Penal. Diante disso, entende-se que a eutanásia é uma conduta imoral que deve ser criminalizada, ainda que haja o consentimento da vítima, pois a vida seria um bem jurídico indisponível.

$\mathrm{Na}$ visăo liberal, todavia, a conduta é compreendida como um suicídio assistido, não devendo ser criminalizada, tendo em vista que todo ser humano tem o direito de optar pela eliminaçáo da dor e do sofrimento, bem como de morrer com dignidade no lugar e no tempo escolhido. Quando o indivíduo se torna um doente terminal, uma parte integral de seu direito consiste em ter o controle do seu próprio destino, pedindo auxílio a outrem para interromper a sua existência no lugar e no tempo de sua livre escolha (DWORKIN, 2003).

O problema é que as pessoas que optam pela eutanásia, seja por se encontrarem em estado terminal ou em qualquer outra situaçáo análoga, não conseguem exercer tal direito por conta própria, necessitando de auxílio para a interrupçáo de sua vida. Apesar da manutenção da plena consciência, a maioria das pessoas que apresenta doenças graves náo tem a capacidade de pôr termo à vida sem ajuda alheia. Um indivíduo em pleno controle de suas faculdades mentais, mas que se encontra ligado a aparelhos que o auxiliam a mantê-lo vivo necessita da assistência de outras pessoas para desligar os equipamentos. Na maioria das vezes o mais procurado para realizar o suicídio assistido é o próprio médico, e muitos mostram-se dispostos a desligar os aparelhos que mantêm vivo o paciente, em estágio terminal, desde que haja manifestação de seu interesse (DWORKIN, 2003). 
Sobre isso, Dworkin (2003, p. 260) expóe:

Contudo, as leis de todos os países ocidentais (com exceção, na prática, da Holanda) ainda proíbem que médicos, ou outros, matem diretamente pessoas que lhes peçam para fazê-lo, injetando-lhes um veneno letal, por exemplo. Assim, o direito produz o resultado aparentemente irracional: por um lado, as pessoas podem optar por morrer lentamente, recusando-se a comer, recusando-se a receber um tratamento capaz de mantê-las vivas ou pedindo para ser desligadas de aparelhos de respiração artificial; por outro, não podem optar pela morte rápida e indolor que seus médicos poderiam facilmente conseguir-lhes.

A proibição da eutanásia, na maioria esmagadora dos países em todo o mundo, deve-se ao fato de que, se fosse legalizada, pessoas que na verdade preferem continuar vivas poderiam ser mortas. Isso porque um paciente terminal, cujos cuidados são caros ou penosos, ou que enfrenta uma situação consternadora para os familiares e amigos, pode se sentir culpado por todo o esforço empregado para a manutenção da sua vida. Além disso, muitos são contra a eutanásia por razóes paternalistas ou religiosas, condenando a prática por acharem que sabem o que é melhor para o paciente terminal e por entenderem que a interrupção da sua vida constitui a violação de um valor indisponível (DWORKIN, 2003).

Para o autor estudado, as pessoas não podem impor suas convicçóes a todos por meio da coercibilidade do Direito Penal, como é o caso da eutanásia. A liberdade é a exigência absoluta e fundamental do amor-próprio, de modo que o sistema jurídico deve incentivar cada um de nós a tomar decisóes individuais sobre a própria morte. $\mathrm{O}$ exercício da liberdade e do direito à consciência confere dignidade ao ser humano, e o governo que nega esse direito é totalitário. Logo, do ponto de vista da eutanásia, o ideal é que o Estado respeite o direito de decidir dos indivíduos (DWORKIN, 2003).

\section{CONSIDERAÇÕES FINAIS}

Ao longo dos últimos anos as discussóes sobre a criminalização de algumas condutas consideradas imorais, tais como a pornografia, o aborto e a eutanásia, têm dividido a opinião de diversos estudiosos e setores da sociedade civil. Nessa linha, 
embora as normas morais exerçam significativa influência na criação das normas jurídicas, nem todas as condutas morais devem ser objeto de regulamentação pelo Direito.

O presente trabalho propôs-se a tratar da criminalização de condutas consideradas contrárias à moral, a partir do entendimento do jusfilósofo norte-americano Ronald Myles Dworkin. Perpassando pela relação entre a moral, o Direito e a liberdade, buscou-se estabelecer os limites da atuação do Direito Penal sobre as questóes morais.

Com efeito, partindo das posiçôes favoráveis e contrárias à ingerência do Direito no campo da moral, estabeleceu-se estudo reflexivo acerca da necessidade de criminalizar tais açóes. Enquanto a corrente liberal entende que tais condutas pertencem ao campo exclusivamente moral, a ala conservadora defende a sua criminalização, contudo, à luz das ciências jurídico-filosóficas, diversos são os motivos que impedem a tipificação penal de condutas imorais.

Nessa perspectiva, o Direito Penal, orientado pela ideia de subsidiariedade - que compóe o substrato do princípio da intervenção mínima (ultima ratio) - apenas atua quando os outros ramos do Direito se mostram insuficientes. A observância ao referido princípio impóe que a criminalização de condutas ocorra somente quando ficar demonstrada a efetiva necessidade de prevenção de lesão a bens jurídicos relevantes. Ressalta-se, ainda, o caráter fragmentário do Direito Penal, que deve se limitar a coibir táo só as condutas mais graves e que violem os bens jurídicos mais importantes.

À luz da filosofia de Dworkin, a criminalização de condutas imorais, tais como a pornografia, o aborto e a eutanásia, resguarda motivos puramente morais, de modo que a tipificação penal dessas condutas contrariaria a liberdade individual dos seres humanos. Sendo a liberdade um requisito essencial, o Estado não deve se imiscuir, por meio de normas jurídicas, na moral privada dos indivíduos. O ser humano deve decidir por si mesmo sobre questôes pertencentes ao âmbito da moral, razão pela qual a criminalização de condutas imorais não demonstra ser uma medida viável. 
Desse modo, no que se relaciona à criminalização de condutas imorais, tais como a pornografia, o aborto e a eutanásia, depreende-se que o direito da sociedade de punir a imoralidade por meio da lei não deve, necessariamente, ser praticado contra todo e qualquer tipo de imoralidade, apesar da importância e influência de alguns princípios restritivos. O Estado deve respeitar a máxima liberdade individual que seja coerente com a integridade da sociedade, ao passo que o Direito deve se abster de interferir em decisóes de cunho pessoal, mesmo que condenáveis por uma parcela da sociedade (DWORKIN, 2002).

\section{REFERÊNCIAS}

ANDREUCCI, R. A. Manual de direito penal. 10. ed. São Paulo: Saraiva, 2014.

BARROS LIMA, A. J. C. de. Direito penal constitucional: a imposição dos princípios constitucionais penais. São Paulo: Saraiva, 2012.

BITENCOURT, C. R. Tratado de direito penal: parte geral. 17. ed. São Paulo: Saraiva, 2012.

BITTAR, E. C. B. Curso de filosofia do direito. 4. ed. São Paulo: Atlas, 2005.

BRASIL. Planalto. Constituição da República Federativa do Brasil de 1988. Disponível em: $<$ http://www.planalto.gov.br/ccivil_03/constituicao/constituicaocompilado.htm>. Acesso em: 10 maio 2017.

CATÃO, A. de L. Filosofia do direito para concursos. Rio de Janeiro: Forense; São Paulo: Método, 2014.

DWORKIN, R. Dominio da vida: aborto, eutanásia e liberdades individuais. Trad. Jefferson Luiz Camargo. São Paulo: Martins Fontes, 2003.

. Levando os direitos a sério. Trad. Nelson Boeira. Sáo Paulo: Martins Fontes, 2002. . Uma questão de princípio. Trad. Luís Carlos Borges. São Paulo: Martins Fontes, 2001.

FERRAZ JÚNIOR, T. S. Introdução ao estudo do direito: técnica, decisão, dominação. 8. ed. Sáo Paulo: Atlas, 2015.

HAYEK, F. A. Von. Os fundamentos da liberdade. Trad. Anna Maria Capovilla e José Ítalo Stelle. São Paulo: Visão, 1983. 
LOPES, L. R. Pornografia: exploração sexual e publicação obscena. 4. ed. Poços de Caldas: CBCN, 2016.

MENEZES, V. A revolução francesa. In: Revista do Instituto do Ceará, ano CIII, 1989. Disponível em: <http://www.institutodoceara.org.br/revista/Rev-apresentacao/ RevPorAno/1989/1989-ARevolucaoFrancesa.pdf>. Acesso em: 21 maio 2017.

MIRABETE, J. F. Manual de direito penal: parte geral. 23. ed. São Paulo: Atlas, 2006.

NADER, P. Introdução ao estudo do direito. 36. ed. Rio de Janeiro: Forense, 2014.

NUCCI, G. de S. Manual de direito penal. 10. ed. Rio de Janeiro: Forense, 2014.

REALE, M. Filosofia do direito. 19. ed. São Paulo: Saraiva, 1999. . Liçōes preliminares de direito. 27. ed. São Paulo: Saraiva, 2002.

ROMA, R. Sociedade de risco e bens jurídico-penais transindividuais: argumentos favoráveis à legitimação no contexto social complexo. 1. ed. Rio de Janeiro: Gramma, 2017.

SECCO, O. de A. Introdução ao estudo do direito. 7. ed. Rio de Janeiro: Lumen Juris, 2001. SILVA, J. De P. e. Vocabulário jurídico. 15. ed. Rio de Janeiro: Forense, 1999.

SIQUEIRA JR., P. H. Lições de introdução ao direito. 4. ed. São Paulo: Juarez de Oliveira, 2002. VELOSO, W. de P. Filosofia do direito. São Paulo: IOB Thomson, 2005.

VENOSA, S. de S. Introdução ao estudo do direito: primeiras linhas. 2. ed. São Paulo: Atlas, 2009.

VILLEY, M. Filosofia do direito: definiçōes e fins do direito - os meios do direito. Trad. Márcia Valeria Martinez de Aguiar. 2. ed. São Paulo: Martins Fontes, 2008. 